\title{
ALTERING THE JUDICIAL MIND AND THE PROCESS OF CONSTITUTION-MAKING IN CANADA*
}

\author{
BRUCE P. ELMAN**
}

This essay deals with the alteration of the Supreme Court of Canada's approach when confronted with alleged violations of civil liberties in the pre-Charter and post-Charter eras. It is noted that certain statutes, such as the Lord's Day Act, were upheld under the Canadian Bill of Rights, but have since been struck down under the Charter of Rights and Freedoms under relatively indistinguishable circumstances. The author asserts that the changes in the approach to civil liberties, and the consequent changes in the Supreme Court's decisions, are the result of a change in judicial attitudes. Among the factors responsible for acting as a catalyst for this shifi in attitude, the author identifies and discusses the change in "principle" resulting from the constitutionalization of rights and the concomitant change in the Court's role, the change in "personalities" resulting from changes in the composition of the Supreme Court, and the "process of constitution-making" used in entrenching the Charter, which gave more legitimacy to the Court's role as interpreter of the Constitution than did the Bill of Rights.
Cette étude a pour sujet les changements d'attitude de la Cour suprême du Canada envers les présumées violations des droits de la personne durant la période précédant la Charte et celle qui la suit. Il est relevé que certaines lois, la Loi du dimanche par exemple, ont été maintenues sous le Bill of Rights canadien puis annulees au nom de la Charte des droits et libertés, dans des circonstances d peu près identiques. L'auseur propose que ces nouvelles façons de percevoir les droits de la personne sont attribuables aux changements d'attitude de la magistrature. Parmi les facteurs qui ont joué un rôle catalyseur d̀ ce sujet, l'auteur reconnait le changement de "principe" qu'explique la constitutionalisation des droits et libertés et sa répercussion sur le róle des tribunaux, le changement de "personnalités" qui résulte de la composition modifiée de la Cour suprême, et le "processus qui a abouti d la constitution" et d l'enchassement de la Charte, lequel a donné d la Cour une plus grande légitimité dans son rôle d'interprète de la Constitution que le Bill of Rights ne l'avait fait.

\section{TABLE OF CONTENTS}

I. ALTERING THE JUDICIAL MIND $\ldots \ldots \ldots \ldots \ldots \ldots \ldots \ldots, 521$

II. CATALYSTS FOR CHANGE $\ldots \ldots \ldots \ldots \ldots \ldots \ldots \ldots \ldots, 527$

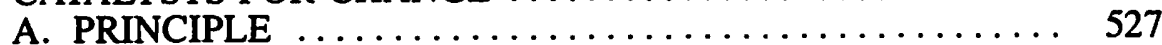

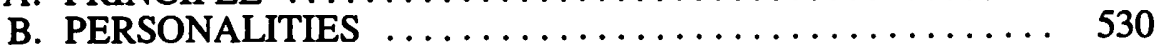

III. THE PROCESS OF CONSTITUTION-MAKING $\ldots \ldots \ldots \ldots \ldots 531$

IV. CONCLUSION: LOOKING TO THE FUTURE . . . . . . . . 533

\section{ALTERING THE JUDICIAL MIND}

Our constitutional history indicates that some legislative initiatives attract more judicial scrutiny than do others. Liquor control regulation and its most radical subspecies - temperance - have been on the Supreme Court of Canada's agenda on a number of occasions.' Likewise, Sunday observance laws have, frequently, attracted the attention of our courts.

* The idea for this essay originally arose in a course, entitled "Comparative Civil Rights: Canada and Israel" , which I taught with Professor David Kretzmer at the Hebrew University of Jerusalem, Israel, during the 1988-89 academic year. It was first presented as a public lecture in the Program of Canadian Studies at the Hebrew University, in April of 1989. I wish to thank Professor Kretzmer and Professor Stephen Goldstein, Dean of the Faculty of Law, for their assistance during my term as Visiting Professor of Law and Canadian Studies at the Hebrew University.

** Professor of Law, University of Alberta. Chair, Management Board, Centre for Constitutional Studies.

1. See, for example, Russell v. The Queen (1882), 7 App. Cas. 829; A. G. Ontario v. A. G. Canada (Local Prohibition), [1896] A.C. 348; A.G. Ontario v. Canada Temperance Federation, [1946] A.C. 193; and $R$. v. Drybones, [1970] S.C.R. 282. 
One of the earliest examples ${ }^{2}$ of the latter occurred in 1903 when the Judicial Committee of the Privy Council struck down the Ontario Lord's Day Act as an encroachment on the legislative powers of the federal Parliament, as granted by s.91(27) of the, then called, British North America Act. ${ }^{3}$ This ruling was reaffirmed by the Supreme Court in its 1955 ruling in the case of Henry Birks \& Sons v. The City of Montreal. ${ }^{4}$ The matter, however, was not closed.

In the fall of 1963, the Supreme Court of Canada heard two cases concerning Sunday observance laws. Oddly enough both cases involved bowling alleys. One such case was brought to the Court by Stanley H. Lieberman. ${ }^{5}$ Mr. Lieberman and his partner, Mortimer L. Bernstein, owned a bowling alley on Union Street in St. John, New Brunswick. On the 23rd of October, 1960 - a Sunday - they had opened their bowling alley in defiance of a St. John city by-law which provided that no person was permitted to keep open a bowling alley (or a billiard or pool room for that matter) on " any weekday between the hour of twelve o'clock at night and the hour of six o'clock in the forenoon or" - and here was the problem - "on Sunday"' 6 Consequently, they were charged with having contravened the by-law. At trial, their defence was not that they had not violated the by-law. Rather, they argued that the by-law was beyond the legislative authority of the Province of New Brunswick. They contended that the by-law encroached upon the criminal law power which was, by section 91(27) of the British North America Act, assigned exclusively to the legislative authority of the Parliament of Canada. ${ }^{\text {? }}$

At trial, the police magistrate accepted this argument, held the by-law to be ultra vires, and acquitted Lieberman and Bemstein. The Crown appealed, however, and, on appeal, they were convicted by the County Court Judge. A further appeal to the New Brunswick Supreme Court, Appeal Division, was dismissed. This brought the matter to the Supreme Court of Canada.

In delivering judgment on behalf of the Court, Justice Ritchie began with the basic assertion, uncontested at the time, that "legislation intended for the purpose of preventing the profanation of the Sabbath is a part of the criminal law in its widest sense and is thus reserved to the Parliament of Canada" ${ }^{8}$ The question still remained, however, whether the by-law's true object - its pith and substance was, indeed, the preservation of the sanctity of the Sabbath or, to the contrary, was directed towards the merely local concern of the regulation of business hours.

Explaining the presumption of constitutionality at the outset of his judgment, Justice Ritchie noted that "it is not to be lightly assumed that any part of the bylaw is directed to a purpose beyond the legislative competence of the enacting authority".?

2. A.G. Ontario v. Hamilton Street Railway, [1903] A.C. 524.

3. U.K., 30 \& 31 Victoria, c. 3. Now the Constitution Act, 1867.

4. [1955] S.C.R: 799.

5. Lieberman v. The Queen, [1963] S.C.R. 643.

6. A Law to Regulate and License Public Billiard Rooms and Pool Rooms and Bowling Alleys in the City of Saint John, July 13, 1908.

7. This was the basis upon which the Privy Council had struck down the Ontario Lord's Day Act in the Hamilton Street Railway case, supra, note 2.

8. Supra, note 5 at 647 . This statement reaffirmed the Court's decision in the Hamilton Street Railway case, supra, note 2.

9. Ibid. at 648 . 
Following this statement, the outcome of the case was not hard to predict. Justice Ritchie concluded that the by-law was not unconstitutional and he affirmed the conviction. According to his Lordship, the by-law was primarily concerned with "secular matters" having as "its true object, purpose, nature, or character, the regulation of the hours at which businesses of special classes shall close in a particular locality in the Province of New Brunswick which is a matter of a merely private nature in that province".${ }^{10}$ This, however, still did not put an end to the matter.

The problem of Sunday observance laws persisted in 1963, and a second case was brought to the Court by Walter Robertson and Fred Rosetanni." They, too, had been convicted of operating a bowling alley on Sunday, but, in their case, contrary to section 4 of the federal Lord's Day Act.$^{12}$ The Lord's Day Act prohibited, inter alia, a person from carrying on or transacting any business of his "ordinary calling" on "the Lord's Day". All appeals in the lower courts had failed, and the matter was brought to the Supreme Court of Canada.

Robertson and Rosetanni challenged the validity of The Lord's Day Act on two bases. They contended that:

1. The question of whether businesses should be open on Sunday was a "matter of a local and private nature"', and thus, should be left to provincial jurisdiction. (One can immediately recognize this as the reverse of the argument which was advanced by Lieberman and rejected by the Court in the preceding case.)

2. The Lord's Day Act was an infringement of their freedom of religion as guaranteed by section 1(c) of The Canadian Bill of Rights. ${ }^{13}$

The Court's answer on the first issue, although at first glance in conflict with Lieberman, was, in fact, predictable. Justice Ritchie noted, as he had in Lieberman, that there had been statutes since well prior to Confederation passed for the purpose of safeguarding the sanctity of the Sabbath (Sunday) and that such legislation had been accepted as falling "under the criminal law power in its widest sense" ${ }^{14}$ In the Court's opinion, the purpose of the legislation was to safeguard the sanctity of the Sabbath. Consequently, on this first ground, the Justices upheld the validity of the Act. The Court still had to address the argument based on the Canadian Bill of Rights.

The Canadian Bill of Rights had come into effect in 1960. It applied to federal legislation only. In 1963, it was still an unknown commodity. Indeed, Robertson and Rosetanni was one of the earliest Bill of Rights cases brought to the Court. The principles enunciated in this case proved to be a harbinger of the Bill's eventual fate. Speaking generally of the Canadian Bill of Rights, Justice Ritchie noted that: ${ }^{15}$

The Canadian Bill of Rights is not concemed with "human rights and fundamental freedoms" in the abstract sense but rather with such "rights and freedoms" as they existed in Canada immediately before the Statute was enacted. (emphasis added)

10. Ibid: at 649.

11. Robertson and Rosetanni v. The Queen, [1963] S.C.R. 651.

12. R.S.C. 1952, c. 171.

13. R.S.C. 1970, Appendix III.

14. Supra, note 5 at 656.

15. Ibid. at 654 . 
This, so-called "frozen rights", theory of interpretation clearly limited the potential development of the Canadian Bill of Rights. According to Justice Ritchie "freedom of religion", as it existed prior to the Bill of Rights, included "complete liberty of religious thought" and provided for the "untrammelled affirmation of religious belief and its propagation, personal or institutional". ${ }^{16}$

Given this interpretation of "freedom of religion", did the Lord's Day Act violate the guarantee of freedom of religion in the Canadian Bill of Rights? Not as far as Justice Ritchie was concerned. He noted: ${ }^{17}$

I can see nothing in that statute which in any way affects the liberty of religious thought and practice of any citizen of this country. Nor is the "untrammelled affirmation of religious belief and its propagation" in any way curtailed.

What, then, was the effect of the Lord's Day Act? In Justice Ritchie's opinion, the effect of the Act was a "purely secular and financial one" - a mere "business inconvenience". It was, most certainly, not an interference with the "kind of religious freedom guaranteed by the Bill of Rights". ${ }^{18}$

As is readily apparent, the approach taken by the Court in these cases was highly deferential towards the legislative branch of government. In each case, the Court found the legislation - the St. John city by-law and the Lord's Day Act respectively - within the legislative jurisdiction of the appropriate legislative body. This deference to the legislative branch stemmed from an adherence to the principle of parliamentary supremacy. The principle of parliamentary supremacy encouraged the view that the Court's role was that of a passive, neutral arbiter in disputes between the two levels of government in Canada's federal system. The Court, in accepting this role, dared not intervene in the legislative realm. ${ }^{19}$

Further, the Supreme Court's passiveness manifested itself in a reluctance to break new ground in the protection of individual rights. Judicial activism was shunned. The Canadian Bill of Rights was given a static interpretation which had the effect of, and may have been designed to, stunt any growth in the protection of human rights and civil liberties. ${ }^{20}$

16. Ibid. at 655 .

17. Ibid. at 657 .

18. Ibid. at 657-658.

19. There were times in the history of the Supreme Court when they acted to safeguard fundamental freedoms such as speech, religion, assembly and so forth. The Court employed two methodologies during these periods of activism. In some cases fundamental freedoms were protected by the Court's rulings that certain legislation violated the scheme of distribution of power in sections 91 and 92 of the Constitution Act 1867. In other cases, the Court held that the impugned legislation violated the "Implied Bill of Rights" which was created from the Preamble to the Constitution Act, 1867. In some cases, these two approaches served as altemative methodologies. For some examples of the application of these methodologies, see the following cases: Reference Re Alberta Statutes, [1938] S.C.R. 100; Switzman v. Elbling, [1957] S.C.R. 285; Saumur v. Ciry of Quebec, [1953] 2 S.C.R. 299; Birks (Henry) \& Sons v. Montreal, [1955] S.C.R. 799. In retrospect, it may well be argued that the Court's apparent "activism" in these cases was actually a "reactivism" to the legislative initiatives of the particular provincial govemments involved in these cases - the Alberta Social Credit Government of the 1930's and Quebec's Union Nationale Government led by Maurice Duplessis in the 1950's. In any event, the use of the "division of powers" approach and the notion of an "Implied Bill of Rights" fell into disfavour and disuse beginning in the late 1960 's. See, for example, the following cases: Walter v. A.G. Alberta; Fletcher v. A. G. Alberia, [1969] S.C.R. 383; N.S. Board of Censors v. McNeil, [1978] 2 S.C.R. 662; A.G. Canada v. Dupond, [1978] 2 S.C.R. 770.

20. The Drybones case, supra, note 3 was the "highpoint" of the Court's expansive use of the Canadian Bill of Rights as a guarantee of individual rights. Cases which followed provided much less protection for individual liberties. See for example: A.G. Canada v. Lavell, [1974] S.C.R. 1349; Hogan v. The Queen, [1975] 2 S.C.R. 574; and A.G. Canada v. Canard, [1976] 1 S.C.R. 170. 
As we have noted, however, the issue of Sunday closing laws never permanently disappears from the Canadian constitutional scene. Twenty-two years later the issue was once again before the Supreme Court of Canada. This case involved a Calgary pharmacy, Big M Drug Mart, which had been charged, as had Robertson and Rosetanni, under the Lord's Day Act. ${ }^{21}$ Like Robertson and Rosetanni, Big M Drug Mart argued that the Lord's Day Act was an infringement of its freedom of religion.

By 1985, however, the Supreme Court's attitude towards this problem had altered markedly. On this occasion, the Supreme Court held that the Lord's Day Act was inconsistent with the principle of "freedom of religion" and was, therefore, of no force or effect. Big M Drug Mart differed from Robertson and Rosetanni not only in final outcome but, also, in the whole tenor of the Court's rhetoric. Justice Dickson's judgment is instructive in this regard. For example, in discussing the concept of "freedom of religion", His Lordship stated:22

The essence of the concept of freedom of religion is the right to entertain such religious beliefs as a person chooses, the right to declare religious beliefs openly and without fear of hindrance or reprisal, and the right to manifest religious belief by worship and practice or by teaching or dissemination. But the concept means much more than that.

Justice Dickson continued: ${ }^{23}$

If a person is compelled by the state or the will of another to a course of action or inaction which he would not otherwise have chosen, he is not acting of his own volition and cannot be said to be truly free. . . . Coercion includes not only blatant forms of compulsion . . . , coercion includes indirect forms of control which determine or limit alternative courses of conduct available to others. Freedom in the broad sense embraces both the absence of coercion and constraint, and the right to manifest beliefs and practices.

Turning his attention, more specifically, to the Lord's Day Act, Justice Dickson characterized the Act as follows: ${ }^{24}$

In proclaiming the standards of the Christian faith, the Act creates a climate hostile to, and gives the appearance of discrimination against, non-Christian Canadians. It takes religious values rooted in Christian morality and, using the force of the state, translates them into positive law binding on believers and non-believers alike. . . . Non-Christians are prohibited for religious reasons from carrying out activities which are otherwise lawful, moral, and normal. The arm of the state requires all to remember the Lord's Day of the Christians and keep it holy. The protection of one religion and the concomitant non-protection of others imports disparate impact destructive of the religious freedom of the collectivity.

Concluding his discussion of the meaning of freedom of religion, Justice Dickson stated: ${ }^{25}$

If I am a Jew or a Sabbatarian or a Muslim, the practice of my religion at least implies my right to work on Sunday if I wish. It seems to me that any law purely religious in purpose, which denies me that right, must surely infringe my religious freedom.

This is a far cry from Robertson and Rosetanni! The decision in Big MDrug Mart represents a marked departure from precedent. It manifests an altering of the judicial attitude towards the protection of individual rights and fundamental free-

21. The Queen v. Big M Drug Mart [1985] I S.C.R. 295.

22. Ibid. at 336.

23. Ibid. at 336-337.

24. lbid. at 337.

25. Ibid. at 338. 
doms. ${ }^{26}$ Why did this occur? The purpose of this essay is to identify those factors which may have served as catalysts for this dramatic shift in the attitude exhibited by the Supreme Court of Canada.

The most obvious reason for this alteration in judicial attitude is the theoretical change in the constitutional status of the Court. On the 17th of April in 1982, Canada patriated its constitution. ${ }^{27}$ Included in the Constitution was the Canadian Charter of Rights and Freedoms, ${ }^{28}$ with its guarantees of legal, political, linguistic, and equality rights. The Constitution became "the supreme law of Canada" and the judiciary acquired the power to declare that laws inconsistent with the Constitution are of "no force or effect". ${ }^{29}$ Thus, the constitutionalization of rights brought with it a concomitant change.in the role of the Court and, perhaps, a shift in judicial attitude.

When the Canadian Charter of Rights and Freedoms came into force, two options were available to the judiciary. They could have viewed the Charter as an evolutionary development, proceeded slowly, avoiding any dramatic break from Canada's constitutional past. After all, as some judges proclaimed, the Charter "was not enacted in a vacuum"..${ }^{30}$ Alternatively, the judiciary could have adopted the position that the Charter represented a distinct break in Canada's constitutional history, and accordingly, given it a generous. interpretation "capable of growth and development over time to meet new social, political and historical realities", thus guaranteeing individuals the full benefit of their Charter rights. ${ }^{31}$ The Supreme Court of Canada has, generally speaking, attempted to balance these two perspectives $^{32}$ but, from the outset, the Supreme Court strongly advocated the principle of a "generous" interpretation.

The change in the constitutionalization of individual rights, then, may be identified as the first factor contributing to the Supreme Court's greater acceptance of an activist role in the protection of rights and freedoms. This first factor, labelled "Principle", is discussed at the outset of Part II of this essay.

26. Nor is the Court's reaction to Sunday closing laws a unique instance of this change in the "judicial mindset". Other cases have created a perception, if not an atmosphere, of jurispnudential revolution. See the following cases as examples: Southam Inc. v. Director of Investigation and Research, [1984] 2 S.C.R. 145; R. v. Therens, [1985] I S.C.R. 613; Reference Re Section 94(2) of the Motor Vehicle Act of British Columbia, [1986] 1 W.W.R. 481 (S.C.C.); R. v. Oakes (1986), 26 D.L.R. (4th) 200 (S.C.C.); R. v. Collins, [1987] 1 S.C.R. 265; R. v. Vaillancourt, [1987] 2 S.C.R. 636; and $R$. v. Morgentaler (1988), 44 D.L.R. (4th) 385. The change in the attitude of provincial courts of appeal towands the protection of individual rights and fundamental freedoms is documented in an empirical fashion in Morton, Solomon, et al, "Judicial Nullification of Statutes Under the Charter of Rights and Freedoms, 1982-1988"' (1990) XXVIII Alta. L. Rev. 396.

27. Canada Act 1982, (U.K.), 1982, c. 11.

28. Part 1 of the Constitution Act, 1982, ibid. (Referred to hereafter as The Canadian Charter of Rights and Freedoms or as simply the Charter.)

29. Constitution Act, 1982 , section 52(1).

30. See Big M Drug Mart, supra, note 21 at 344.

31. Southam Inc. v. Dir. of Investigation, supra, note 26 at 155-156. Sometimes both of these perspectives were expressed in the same case. For example, see Big M Drug Mart, supra, note 21 at 344.

32. Indeed, Big M Drug Mart was not the last Sunday observance case to reach the Supreme Court. The case of Edwards Books and Art Lid. v. The Queen, [1986] 2 S.C.R. 713 is a good example of the Court's attempt to balance interests. In this case, the Reiail Business Holidays Act R.S.O. 1980, c. 453, which contained a sabbatarian exception, was held to be constitutionally valid. 
No one cause, however, can account for the dramatic jurisprudential developments which have occurred since the Charter came into force. Constitutions are not documents with independent life. They require those charged with their enforcement to inject them with vitality. Perhaps, a second factor was the change which had occurred in the composition of the Supreme Court of Canada just at the critical time when Charter litigation reached the high Court. It is important for us to examine any changes in the composition of the Supreme Court of Canada that occurred contemporaneously with the onslaught of Charter cases. This factor, which we have called "Personalities", could have had a major effect on the "institutional attitude" of the Court to the protection of rights. "Personalities" are briefly discussed at the conclusion of Part II.

Factors related to "Principle" and "Personalities" aside, it is the author's view that it was the "Process of Constitution-making" that was critical in shaping the Supreme Court's attitude towards the protection of rights as guaranteed by the Charter. This is a difficult thesis to demonstrate. The "Process of Constitutionmaking" will be discussed in Part III.

The essay concludes with some observations regarding the challenges which face the Court in the future.

\section{CATALYSTS FOR CHANGE}

\section{A. PRINCIPLE}

By "Principle", I refer to the theoretical change in the role of the judiciary. This may, in part, account for the change in the Supreme Court's attitude towards the protection of individual rights. When the Constitution Act, 1982 (and, consequently, the Charter) came into effect, the Constitution was made the supreme law of the land and any law inconsistent with it was, from that time, of no force or effect. Thus, from April 17, 1982, Parliament was no longer supreme; rather it was the Constitution that was supreme. The role of the Court, then, became one of being the guardian of the Constitution and, thereby, the overseer of the constitutionality of governmental action.

From the earliest cases, the Supreme Court attempted to dictate guidelines for the interpretation of the Charter which would coincide with the Court's new role in Canadian society. The principles enunciated in those early cases provided the basis for the jurisprudential developments which followed. ${ }^{33}$

The primary principle enunciated by the Court, was the idea that "constitutions are different". ${ }^{34}$ Constitutions, are, of course, different from ordinary statute law. A constitution is more important than other laws as it is the embodiment of the values, central to the society it serves. Constitutions are designed to last a greater length of time than ordinary statutes and are, consequently, more difficult to alter, amend or repeal. They are, thus, written in broader and less precise language providing more scope for judicial interpretation. This principle is not a novel one in Canada.

33. The principles of Charter interpretation are discussed in Gibson, The Law of the Charter: General Principles, (Toronto: Carswell: 1986) at 43-84 and Hogg, Constitutional Law of Canada (2nd Edition), (Toronto, Carswell: 1985) at 650-664.

34. Southam Inc., supra, note 26 at 155. 
The principle had been noted as early as 1930 in the so-called "Persons Case " 35 In that case Viscount Sankey, speaking for the Privy Council, stated that the British North America Act had "planted in Canada a living tree capable of growth and expansion within its natural limits" ${ }^{36}$ This led, his Lordship to the conclusion, progressive for his day, that "women" were to be included in the term "persons"' and could, thereby, attain the lofty status of senator in the Canadian Parliament. The "living tree doctrine", as it became known, seems to have found a more comfortable existence in the interpretation of the Charter than it ever did in regard to the British North America Act.

From this starting point, deeply rooted in Canadian constitutional tradition, the Supreme Court derived the proposition that the Charter was a "purposive" document - its purpose being "to guarantee and to protect, within the limits of reason, the enjoyment of the rights and freedoms it enshrines'. ${ }^{37}$ Thus, the purpose of the Charter is to constrain govemment action which threatens these guaranteed rights and freedoms. According to the Court, the consequences of this approach for the interpretation of the Charter are clear: $:^{38}$

The interpretation should be a generous rather than a legalistic one, aimed at fulfilling the purpose of the guarantee and securing for individuals the full benefit of the Charter's protection. (Emphasis added)

What are the general implications of such an approach? First, in the constitutional realm, the Supreme Court is no longer bound by precedent and can certainly not be bound by pre-Charter jurisprudence. In a more particular application of this notion, the Court is not bound by jurisprudence regarding the Canadian Bill of Rights. In one of the earliest Charter cases to reach the Supreme Court, $R$. v. Therens,${ }^{39}$ the Justices made it clear that they could not, in addressing the Charter, blindly adopt the interpretation given to the rights contained in the Canadian Bill of Rights, even where the text providing for those rights was similar or even identical to Charter rights.

Thirdly, other early cases demonstrate the Supreme Court's resolve not to be influenced by American jurisprudence, but rather to fashion a, so to speak, "made in Canada" constitutional regime. Concerning the American dichotomy, for example, between "procedural and substantive due process", Justice Lamer stated: ${ }^{40}$

We would, in my view, do our own Constitution a disservice to simply allow the American debate to define the issue for us, all the while ignoring the truly fundamental structural differences between the two Constitutions.

Finally, the Supreme Court firmly rejected the notion that a concept of "original intent" can in any way limit the judiciary's role as the interpreters and arbiters of the Charter. This, in spite of the fact that the "origin" of the Charter is so recent

35. Edwards v. A.G. Can., [1930] A.C. 124.

36. Ibid. at 136.

37. Southam Inc., supra, note 26 at 156.

38. Big M Drug Mart, supra, note 21 at 344.

39. Supra, note 26.

40. Reference Re Section 94(2) of the Motor Vehicle Act of British Columbia, supra, note 26 at 491 . Nonetheless, it would appear unlikely that American jurisprudence has had no effect on Supreme Court decisions regarding the Charer. 
and that such a volume of "evidence" exists as to the "intent" of the originators. ${ }^{41}$ The Justices have indicated, in the strongest possible terms, that they will not be constrained by interpretations given to the Charter by those civil servants and government Ministers who testified before the Joint Senate and House of Commons Committee on the Constitution. Commenting on this issue, Justice Lamer stated: ${ }^{42}$

Moreover, the simple fact remains that the Charter is not the product of a few individual public servants, however distinguished, but of a multiplicity of individuals who played major roles in the negotiating, drafting, and adoption of the Charter. How can one say with confidence that within this enormous multiplicity of actors, without forgetting the role of the provinces, the comments of a few federal civil servants can in any way be determinative.

Perhaps one example, of the "large and liberal" interpretation at work would be useful. It appears that the French and English versions of the Charter were developed without due regard to obtaining exact translations. ${ }^{43}$ Section $24(2)$, for example, provides in the English version that evidence obtained in a manner inconsistent with the Charter shall be excluded if its admission "would bring the administration of justice into disrepute" while the French text demands exclusion if the evidence's admission " est susceptible de déconsidérer l'administration de la justice" or could bring the administration of justice into disrepute. ${ }^{44}$ Clearly, the French version is more helpful to an accused person.

Normally one might solve this problem by adopting the wording of the original and disregarding the translation. However, the Charter appears to have been drafted simultaneously in both French and English. Therefore, at least legalistically speaking, there is no "original" version which carries greater authority. Indeed, section 57 of the Constitution Act 1982 provides that the English and French versions are equally authoritative. In this particular instance, the Supreme Court resolved the problem by accepting the less onerous French version. Justice Lamer noted: 45

As one of the purposes of section 24(2) is to protect the right to a fair trial, I would favour the interpretation of section 24(2) which better protects that right, the less onerous French text.

Thus, we now have a broader rule for the exclusion of evidence than we did prior to the existence of the Charter. As this example demonstrates, the Supreme Court has been guided by the principle that the Constitution is different from a normal statute, that it is a purposive document, and that it requires a generous interpretation in order to advance its purpose.

Nor was the Court's new role as protector of the Constitution an entirely unfamiliar one. The Court had been the "guarantors", so to speak, of the supremacy of the British North America Act. Their function as arbiters of that Act had two important consequences for their future role in safeguarding Charter rights. First of all, the British North America Act did guarantee some rights and the Court, during its history, had acted to safeguard those rights. More importantly, the British North

41. See the discussion of the admissibility of excerpts from the Proceedings and Evidence of the Special Joint Committee of the Senate and of the House of Commons on the Constitution of Canada, ibid. at 496-501.

42. Ibid. at 501 .

43. For a discussion of this problem, see Gautron, "French/English Discrepancies in the Charter" (1982) 12 Man. L.J. 220.

44. Charter, section 24(2). Emphasis added.

45. Supra, note 26 at 287. 
America Act established in Canada the concept of constitutionally entrenched, judicially enforceable rules which were superior to authority of either level of government.

Thus, the idea of judicial review of government activity, including legislative activity, was not foreign to the Court as it undertook its role as the protector of individual rights and freedoms under the Canadian Charter of Rights and Freedoms.

Yet, this factor alone cannot explain the pronounced shift in the Court's attitude towards the protection of individual rights and fundamental freedoms. A second possible factor involves the personalities on the Court.

\section{B. PERSONALITIES}

The composition of the Supreme Court of Canada went through a drastic change in the years just prior and immediately subsequent to the coming into force of the Charter. One must appreciate that, although the Charter came into force on the 17th of April in 1982, only a few cases had reached the Supreme Court by 1984. The majority of the cases, indeed, were decided after 1985 . With this date in mind we can note the following changes in the Court's composition.

First, Justice Brian Dickson was appointed Chief Justice of the Court on April 18, 1984, following the death of Chief Justice Laskin. Although Chief Justice Laskin was considered a liberal, Justice Dickson, for some time prior to his appointment as Chief Justice, had been the intellectual leader of the liberal wing of the Court. This was, perhaps, the most critical change in the composition of the Court during the post-Charter period.

Secondly, Justice Laskin was replaced on the Court by Justice Gerald LeDain. Justice LeDain, a former Dean at Osgoode Hall Law School, had served as the Chairman of a Royal Commission examining the Non-Medical Use of Drugs. The Commission's report was generally seen as being a very progressive document. He joined the Court on the 29th of May, 1984, and was a member of the activist wing of the Court.

In the pre-Charter era the Conservative faction of the Supreme Court was led by Justices Louis-Phillipe Pigeon, Ronald Martland, and Roland Ritchie. Justice Pigeon was replaced by Justice Antonio Lamer who had been President of the Law Reform Commission of Canada. Justice Lamer joined the Court on the 28th of March, 1980. Two years later, on the 30th of March, 1982, Madame Justice Bertha Wilson replaced Justice Martland, and on the 16th of January, 1985, Justice Ritchie was replaced by Justice Gerald LaForest. All three Justices can be considered, admittedly to varying degrees, to be members of the liberal wing of the Court.

Thus, in terms of its composition, the Supreme Court was becoming more liberal in philosophy just as its involvement with the Charter was beginning.

The importance of the makeup of the Supreme Court cannot be underestimated. And yet, what was truly unique about the realization of a charter of rights for Canada was the public nature of the process which produced it. It is to the process of constitution-making that we now turn. 


\section{THE PROCESS OF CONSTITUTION-MAKING}

As important as the factors of principle and personalities were in the alteration of the Court's attitude towards human rights, the process that Canada went through in "making" its Constitution may have been the most important catalyst of all.

The story of the process that produced the Charter and the Constitution Act, 1982, of which it is a part, is a long and rather exhausting tale. ${ }^{46}$ Let us focus on only one period during the process of constitutional reform - that beginning in October of 1980. During that October, Prime Minister Trudeau served notice that the government would unilaterally patriate the constitution and include in it a charter of rights. To that end, a draft resolution was tabled, and a Joint Senate and House of Commons Committee on the Constitution, co-chaired by Senator Harry Hays and Member of Parliament Serge Joyal, was established to examine the contents of the draft resolution and, of course, the Charter of Rights itself.

Although much of the earlier activity on constitutional reform, such as the Continuing Committee of Ministers on the Constitution and the Pepin-Robarts Task Force, had taken place in the public eye, the Hays-Joyal Committee exemplified the public nature of the process of constitution-making which gripped Canada in $1980-81$. Some statistics may illustrate this point. ${ }^{47}$

The Hays-Joyal Committee held 106 meetings on 56 sitting days involving 267 sitting hours. Clause by clause consideration of the draft resolution occupied 90.5 hours. As of February 2nd, 1981 (11 days before the last sitting day) the Committee had received letters, telegrams and briefs from 914 individuals and 294 groups.

The Minister of Justice, Jean Chretien, appeared as a witness before the Committee 39 times and the Solicitor-General appeared a further 9 times as acting Justice Minister. The Premiers of Nova Scotia, New Brunswick, Prince Edward Island, and Saskatchewan and the representatives of the territorial governments of the Yukon and Northwest Territories also appeared as witnesses before the Committee. In total 104 individuals and groups appeared before the Committee. Among the individuals who appeared were Gordon Fairweather, Chairman of the Canadian Human Rights Commission, Max Yalden, the Commissioner of Official Languages, Reverend Edward W. Scott, Primate of the Anglican Church of Canada, and constitutional scholars Peter Russell, Maxwell Cohen, Gil Remillard, and Gerald LaForest.

The multitude of groups represented an extremely broad crosssection of Canadians. ${ }^{48}$

1. Womens Groups including the Advisory Council on the Status of Women and the National Action Committee on the Status of Women.

2. Ethnic Groups including the Canadian Consultative Council on Multiculturalism, The Italian-Canadian National Congress, the National Association of Japanese Canadians, the National Black Coalition, the Ukrainian Canadian Committee, and the Canadian Jewish Congress.

46. The history of this process is documented in Romanow, Whyte, and Leeson, Canada . . . Notwithstanding (Toronto, Carswell/Methuen: 1984).

47. Proceedings of the Joint Senate/House of Commons Committee on the Constitution, Issue No. 57.

48. Ibid. 
3. Linguistic Groups such as Association Canadienne-Francaise de l'Ontario, La Federation des Francophones Hor's Quebec, and the Council of Quebec Minorities.

4. Political Parties including the New Democratic Party of Alberta, the Progressive Conservative Party of Saskatchewan, and La Parti de l'Union Nationale de Quebec.

5. Native Groups were numerous. No fewer than 16 groups appeared as witnesses. Included were the Association of Metis and Non-Status Indians of Saskatchewan, the Indian Association of Alberta, Indian Rights for Indian Women, the National Indian Brotherhood, and the Union of Ontario Indians.

6. Religious Groups included the Church of Jesus Christ of Latter Day Saints, the United Church of Canada, the Ontario Conference of Catholic Bishops and the Mennonite Central Committee.

7. Law Enforcement Groups such as the Canadian Association of Police Chiefs and the Canadian Association of Crown Counsels also appeared.

8. Civil Liberties Groups included the Canadian Civil Liberties Association, the New Brunswick and Saskatchewan Human Rights Commissions, and the Public Interest Advocacy Centre.

9. Other Groups representing a broad spectrum of issues appeared as well. These included the Canadian Chamber of Commerce, the Canadian Bar Association, the Canada West Foundation, the Canadian Catholic School Trustees, the Protestant School Board of Greater Montreal, the Canadian National Institute for the Blind, the Canadian Association of the Mentally Retarded, the Canadian Council on Children and Youth, the National AntiPoverty Organization, and the Federation of Canadian Municipalities.

Therefore, a very strong case can be made for the proposition that the Constitution Act 1982 and the Canadian Charter of Rights and Freedoms not only had the support of the people of Canada through their elected representatives but in fact was a product of the efforts of all Canadians whether elected officials or not.

Some further statistics support this theory of the Charter as having, so to speak, "emanated from the people". As a result of the representations made to the Committee, numerous amendments were made to the proposed Charter. The government proposed 58 amendments, all of which were approved. The Progressive Conservative Party proposed 22 amendments of which 7 were approved, and the New Democratic Party proposed 43 amendments, 2 having been approved. Thus a total of 67 changes were made in the Constitution Act 1982 as a result of the Hays-Joyal Committee hearings. ${ }^{49}$

Nor was this merely a matter of the number of amendments made. We must recognize that the Supreme Court's task in assuming its new role was made significantly easier by the text of the Charter in contrast to the wording which had been used in the Canadian Bill of Rights or, for that matter, in the original Charter proposal.

Numerous examples exist. A few should suffice. First, section 1 in the original Charter proposal provided that the rights and freedoms contained in the Charter were to be "subject only to such reasonable limits as are generally accepted in a 
free and democratic society with a parliamentary system of government".$^{50}$ The phrase "generally accepted" was altered to the stricter "demonstrably justified" and the last phrase referring to "a parliamentary system of government" was deleted entirely. ${ }^{51}$ These changes enabled the Court to place a heavier onus on the government to justify its legislative actions.

A second example may be offered. The "right to counsel" provision in the Canadian Bill of Rights provides that everyone who is arrested or detained has the right to "retain and instruct counsel without delay" 52 while the Charter adds to that the right "to be informed of that right". Thus, the scope of the "right to counsel" is much broader and more meaningful under the Charter.

The Charter, then, by its very text indicated to the Court that a new judicial attitude had to be adopted towards the protection of guaranteed rights and fundamental freedoms.

The public's awareness of the constitutional debates of that time was heightened by legal challenges to the notion of unilateral patriation brought by the governments of Manitoba, Newfoundland, and Quebec..$^{53}$ The questions posed were of such importance and the interest so high, that the Supreme Court of Canada's decision was delivered live on television.

The public nature of the process did not end with the coming into force of the Charter. At no time in Canadian history has a more extensive public, professional, and judicial educational program been undertaken than was done concerning the Charter.

It may well be argued that the Canadian people had high expectations of what the Charter would mean for Canadian society, and the Supreme Court was well aware of those expectations. This public participation in, and support for, the process of constitutional change, it is suggested, was the primary factor in the shaping of the Supreme Court's attitude towards the protection of individual rights and fundamental freedoms.

\section{CONCLUSION: LOOKING TO THE FUTURE}

The past two years have been marked by further dramatic changes in the composition of the Supreme Court of Canada. On April 15th, 1987, Madame Justice Claire L'Heureux Dube was appointed to replace Justice Julien Chouinard. In June of 1988, John Sopinka replaced Justice Willard Estey and, on the 1st of February of 1989, Justice Charles Gonthier and Peter Cory replaced Justices Beetz and LeDain. On the 15th of February, 1989, Justice William McIntyre, the conservative voice on the Court throughout the first 7 years of Charter adjudication, resigned. He was replaced by Madame Justice Beverly McLachlin of the British Columbia Court of Appeal.

This brings the number of Justices appointed in the last 2 years to 5, or a majority of the Court. In such a situation, the future direction of the Supreme Court is a matter of speculation only.

50. Proposed Resolution Respecting the Constitution of Canada, Schedule B, s. 1.

51. Charter, section 1.

52. Canadian Bill of Rights, s. 2(c) (ii).

53. See Reference Re Amendment of the Constitution of Canada (Nos. 1, 2, and 3), [1981] 1 S.C.R. 753. 
We can, however, with some degree of certainty, identify the challenges which await them. First and foremost, will be the interpretation and application of the Equality Rights provision ${ }^{54}$ of the Charter. This section came into effect in 1985 and cases have just begun to percolate through the Court's system to the Supreme Court of Canada. In the first judgment involving this provision - delivered February 2, 1989 - the Court declared the citizenship requirement for membership in the British Columbia Bar to be unconstitutional. ${ }^{55}$ Many other equal protection cases await the Court. ${ }^{56}$

Important cases involving the fundamental freedoms $\mathrm{s}^{57}$ - religion, expression, assembly, and association - await the Court's attention as well. To cite only one example, cases involving Canada's hate propaganda law have just recently been argued before the Court. In these cases, the Court will have to decide whether to follow the position, advanced by the Alberta Court of Appeal, ${ }^{58}$ that the prohibition against the "wilful promotion of hatred" is a violation of freedom of expression which cannot be justified, or the Ontario view ${ }^{59}$ that the Criminal Code provision is not a violation of freedom of expression at all or, if it is, that it is reasonable and justifiable in a free and democratic society.

The Court will continue to struggle with the admissibility of evidence. In particular, the Court must meet the challenge posed by some provincial Appeal Courts which appear to be returning to the Pre-Charter position. ${ }^{60}$

Most importantly, the Court will be faced with the continuing problem, inherent in our constitutional regime, of balancing the rights of the individual with the rights, and indeed the welfare, of the society as a whole. For it is the fashioning of a constitutional ethic which protects the individual and, at the same time, the collectivity which is the real challenge facing the Supreme Court of Canada.

54. Charter, section 15.

55. Andrews v. Law Society of British Columbia, [1989] 2 W.W.R. 289 (S.C.C.).

56. The fact that one-third of the Supreme Court are women may affect the jurisprudential development of section 15 of the Charter.

57. Charter, section 2.

58. Keegstra v. The Queen, [1988] 5 W.W.R. 211 (Alta. C.A.).

59. Andrews and Smith v. The Queen (1988), 28 O.A.C. 161 (Ont. C.A.).

60. For an analysis of this issue, see Elman, "Retuming to Wray: Some Recent Cases on Section 24 of the Charter" (1988) 26 Alta. L. Rev. 604. 